\title{
Institutionalism and Culture in Strategies of Multinational Firms, Case of Johnson Controls Inc.
}

\author{
José G. Vargas-Hernández, M.B.A.; Ph.D. \\ Lic. Zayda Anahí Naranjo Martínez \\ Centro Universitario de Ciencias Económicas \\ Administrativas, Mexico
}

\begin{abstract}
The aim of this paper is to analyze both internal and external aspects posing a risk in the operation for the multinational Johnson Controls in its subsidiaries in United States and Mexico from the point of view based on institutions; the main challenge to initiate the investigation is do have some impact in the culmination of the goals both of workers and of the same organization?, how to influence the institutions in the organizational environment, for the decommissioning of some branch/ subsidiary. The method used was Analytics to evaluate all the information obtained from the company and thus achieve the objectives required for this research, applied the theory based on the vision of institutions in multinational companies. For results of the analysis, we first had to get to know the real development of multinational enterprises, and then focus on the enterprise objective Johnson Controls Inc.
\end{abstract}

Keywords: Institutionalism, multinational, theory based on the institutionalism.

\section{Introduction}

The aim of this paper is to analyze the internal and external issues that pose a risk in the operation for the multinational Johnson Controls Inc. in its subsidiaries in the United States and Mexico from the point of view based on institutions. Also to analyze whether this point of view has any impact at the height of the aims of both workers and the same organization as the company presents organizational communication problems because of the 
diversity of cultures that have in their human resources. Thus, subcultures are identified as parts of the multinational firms, each one with congruent systems of assumptions and values, although opposite cultural patterns.

Note that these problems are not at all branches, and seeks to determine which factor is the one having the most influence on this event occurs. The issue of multinationals has a higher power of influence and attract the same problems of these organizations because the larger the company the greater the communication and organizational conflicts.

\section{Background}

It is thought that a multinational firm must be both effective and efficient company in every way, as it does achieve competition in the economic globalization processes in which everybody lives today. Therefore, always it is believed that a company as big as Johnson Controls Inc. should work perfectly in either the organization or in the production area, but it does not usually asks about why these companies come to close their plants? Or what is it really failed? Do you have a social factor that may influence the decision to close? To answer these questions, it must first focus with what kind of human resources the company has to understand the type of organizational culture diversity that has Johnson Controls and whether it influences the communication barriers faced by the company.

Multinational companies (Encyclopedia of Economics, 2009) were born after World War II when private direct investment in third countries began to be associated with the expansion of big business and the creation of subsidiaries; this was aimed for spatial diversification and establishment of an extension of the diversifying strategy sector, only to reduce risks and uncertainties that enterprises always carry.

The multinational firm developed rapidly in the United States during the 1950s and 1960s while were developed agreements or inter-enterprise collaboration and the processes of horizontal and vertical integration multiplied. These companies are of type $\mathrm{H}$ with highly decentralized structures that invest heavily in direct investment. Although the term is relatively 
recent, multinationals are economic organizations that have been the basis of the capitalist system from its origins as they have always been in constant change and growth, adapting to historical variations of both the economy and the market. The term multinational (Encyclopedia of Economics, 2009) or transnational refers to that firm which has companies with operations in several countries.

Each multinational firm has its own power of decision and control but is regularly monitored by the headquarters at the home country. The headquarters may be registered in one country and be just part of foreign ownership. At the same time, the multinational firm has the ownership, management and control of productive assets in more than one country depending on what its needs. Multinational companies install their different manufacturing processes, marketing or provisioning, as well as having a functional capacity, decentralized management by objectives or divisional organization. Multinational firms are also the paradigmatic institutions of the capitalist system, its symbol since they are the main representatives of globalization. Globalization (Beck, 2008) is the continued expansion of the market; consequently, the multinational firm is an adaptation of a current business to the same global expansion.

The organizational structure of multinational firms, as sustained by Hymer (1972), is about the distribution of economic activity worldwide. This means that the activity of multinationals are divided into different processes like any company, just for the sake of transacting in a world market, and have the appropriate organization for success as desired. Therefore, in this theory Hymer (1972) reveals the inadequacy and imperfection of market transactions as the reason for the internal growth of the firm, or a combination of economy of scales and comparative advantages of the coordination of production through internal hierarchies vs. coordination of the entire market.

\section{How to Handle the Institutionalism in the Renowned} Multinational Company Johnson Controls Inc.

Institutionalism and evolutionary economics approaches consider 
firms as dynamic economic agents of economic and social institutional networks. The theory based on institutions suggests that companies make their strategic choices based on the interaction between institutions and the organization, seeking institutional legitimacy regarding the normative, policy and regulatory systems of the country. This perspective has emerged in recent years as one of the most appropriate theoretical frameworks for analyzing strategic decisions of companies from developed economies (Peng, 2010). However, in certain destinations, multinational firms face institutional barriers higher than those faced by companies from other countries.

The theory of the multinational firm handles items of a vision based on the institutionalism of business strategies (Peng, 2010). It had been mentioned about how companies when facing strong international competition have to implement different strategies are needed, so it has to be in every place where is to become consolidated, as it not only takes into account the state and society, but all possible factors that may influence the success of it and implement appropriate strategies.

References to the theory of strategy based on empirical research on a number of Asian countries (Scott, 1995, p. 146) consider four substantive areas: 1) strategies for providers, 2) business strategies, 3) diversification strategies, and 4) growth strategies. All this just to get an understanding of the theories with a view based on the institutions of the business strategy, in order to achieve that a company has the right strategies to make the right decisions, and then it should consider these areas substantive as described above.

Now it could be questioned what are the institutions? Institutions are simply the rules of the game, i.e. they are limitations designed to shape human interactions (Scott, 1995, p. 33). In addition there is a reference to the institutional framework of how to provide stability and meaning to social behavior. A representative figure of the theories of institutionalism is Douglass North, who has its antecedents in American institutionalism in the early decades of the last century. As such, it should be noted that between these two intellectual movements there is neither clear evolutionary sequence of ideas, nor between them and neo institutional approaches that are spoken 
today (North, 1990).

The transaction costs were developed by Coase (1937). The transaction costs refer to rationalize why multinationals prefer to reduce their transaction or negotiation costs (Coase, 1937) at the expense of employing workers not as focused or experienced in the area needed to achieve the desired goals for the company. It is usually much easier to hire employees from different countries who do not require the corresponding salary to the level of preparation that employees have, just for the need to work. Then, actually boasts the least value of their work.

An application of ideas based on the interpretation of the phenomenon of multi-nationalization of firms has been made by McManus (1972) and Rugman (1981). This theoretical framework is leading to analyze that the existence of transaction costs is the key for multinational companies to stabilize the foreign subsidiaries. Multinational firms operate directly under the central control (vertical integration) as opposed to operating through the market. This situation results in that workers are discouraged by Johnson Controls through all the existing communication barriers and also by the devaluation of labor. The multinational firm based on its home country try to minimize these costs as much as possible in their affiliates operating abroad in other host countries, but without considering the consequences that could have the company by not perfectly monitoring these contracts.

Nowadays, it dominates the view that the multinational firm operates primarily the ownership of knowledge and information. Economies of scale encourage concentration of global production in a few locations and discourage multinational operations. Knowledge, however, is an asset easily transferable internationally and this favors the multi-nationalization.

\subsection{Organizational Structure}

In his research on the administration of large U.S. firms, Chandler (1961) identify three levels of work, three levels of decision-making and three levels of policies. Level III, the minimum, refers to the administration of the daily operations of the company. Level II is responsible for the coordination 
of managers working in Level III. The I-level functions of top management and senior management are targeting and planning. This level sets down the framework within which low levels operate. Then the flow of communication always fluctuates in these three levels. Therefore, one must be very careful about any barriers arising, as it provides inadequate communication.

Making and adequate emphasis on strategies and firm performance are determined by the same organizations and covering institutions, cultures and ethics as they are supported by the 3 pillars: Regulatory, educational and cognitive (Peng, 2010). All this emphasis on institutions is just to reduce the uncertainty given by the markets that are generated to the company or made them by the firm. North (2005) argues that institutions are socially embedded. Institutions generate different scenarios where they face uncertainty in every way.

North $(2005,36)$ tries to explain what the mechanism for achieving a good institution is: Cultural heritage provides a structure of artifacts that not only plays a key role in shaping our decisions as social players, but also provides clues about the dynamic success or failure over time. In essence, the richer the structure of artifacts, the greater is the reduction of uncertainty for decision making. In time, while the richer is the context in terms of providing creative experimentation and competition, the more likely is the survival of a society (North, Understanding the Process of Economic Change, 2005, p. 36).

Then to the conclusion that Arellano (2009) comes about regarding what is needed for a good institution, is that a country's cultural heritage and how it provides a set of beliefs, tools and institutions define our role as players on the social scene. The more rich than this, the lower the uncertainty, which generates a kind of experimentation and creative competition (Arellano, 2009), which creates some chance for survival in society.

Institutions become good because they generate fair and loyal competition and experimentation, enabling long-term deal with the uncertainties that come to emerge. Therefore, it is evaluated the potential of institutions in developed countries such as Johnson Controls to create some context and cultural factors as they do to develop the competence and adequate 
experimentation and testing for each country, making the consolidation and adaption according to their interests.

It is questionable to wonder if it really the institutions can be designed or are effects of interactions. As mentioned by North (2005), the institutions are difficult to control rationally, making difficult to know in advance how society can react, as these are organized by a group of people in a particular generation. The institutions are related to a direct form of power, which is competition. Thus, when a multinational corporation at the time of wanting to build and consolidate its position in a specific market, generates strong competition. There are evidences that some competitors will be better prepared and better able to adapt to a local environment and dominate that market as the weight that gives the experience gives the multinational firms a certain comparative advantages.

Competition leads to the inequality of capabilities, opportunities, skills, intelligence, all to achieve differentiation. One of the disadvantages that may result being a multinational firm is the diversity of all these factors of local differentiation. At the time of adding diversification which is counted in human resources can become abysmal and of concern, or may have the opposite effect, depending directly from the company. This outcome depends either from the characteristics of people in the place where such branch is located or simply the ethical challenges available to each person to carry out the objectives of the multinational firm (Table 1).

Table 1. Branches and plants of Johnson Controls

\begin{tabular}{|l|l|}
\hline Region / Country & Plants \\
\hline United States and Canada & Headquarters in Milwaukee. \\
& Technology Centers in Plymouth and \\
& Milwaukee. \\
& 7 integrated plants. \\
& 4 distribution centers. \\
\hline
\end{tabular}




\begin{tabular}{|c|c|}
\hline South America & $\begin{array}{l}\text { Technology Center in Sorocaba } \\
2 \text { plants. } \\
3 \text { centers of distribution in Brazil, Argentina } \\
\text { and Venezuela. }\end{array}$ \\
\hline Mexico & $\begin{array}{l}\text { Headquarters in Monterrey } \\
\text { Technology Center in Monterrey } \\
5 \text { plants in }\end{array}$ \\
\hline \begin{tabular}{|l|} 
Europe \\
\end{tabular} & $\begin{array}{l}\text { Headquarters in Hannover. } \\
\text { Technology Center in Hannover. } \\
8 \text { Plants. }\end{array}$ \\
\hline Asia & $\begin{array}{l}3 \text { plants in South Korea (Kumi). } \\
\text { China (Shangai). } \\
\text { India (Amara Raja). } \\
\text { Sales offices in Japan. }\end{array}$ \\
\hline
\end{tabular}

Source: (Johnson-Controls, 2010), Sucursales, johnsoncontrols. Obtenido http://www.johnsoncontrols.es/content/es/es/sobre_la_empresa/nuestra empresa/premios_y_reconocimientos.html

So the institution is not only a result of any set of interactions, but also a product of competition for power among the factors that are necessary for decision making over time, allowing them to go on with an advantage over others. But given time, the atmosphere is so flawed that it cannot really do that the workers become loyal to the company. Therefore, this atmosphere affects the acceptance of responsibility of employees (Peng, 2010) and conformed to social capital. Putnam (1993) conducted an empirical study that refers to the degree of trust in any given society, and it also influences the process of making decisions.

Thus, it is important to know what kind of employees are integrated into the company and focused on the mission, vision and objectives of the multinational firm, but a really decisive factor is the drama of development of the people due to lack of trust. Much of trust enhancement depends on social work to local societies conducted by business. Strategic planning and building trust are needed to make the proper observance of the multinational 
firm Johnson Controls Inc. and get to know the reasons for which the company has successes or failures.

\section{Implications of Culture in Strategy of Multinational Firms}

Culture is defined from the point of view of different perspectives (Jenks, 1993; Stohl, 2001; Ting-Toomey, 1999). "Culture is a set of values shared by a group of people frequently used to distinguish one group from another." (Gibson \& Gibbs, p.284). "Culture is the set of deep level values associated with societal effectiveness, shared by an identifiable group of people" (Gibson \& Gibbs, p. 474). Culture is "a history of experiences and concomitant expectations that shape their encounters" (Gibson \& Gibss, p. 37). Culture is "broadly defined as characteristic ways of thinking, feeling, and behaving shared among members of an identifiable group" (Gibson \& Gibbs, 2006, p. 460). Culture is defined as a "patterned ways of thinking, feeling, and reacting," which "Both national and professional cultures come into play." (Gibson \& Gibbs, p.114).

Conceptualization of culture is related to salience and how consequential it is (Brannen, 2003; Osland \& Bird, 2000). Conceptualization of culture may include multiple nationalities, demographic features, multiple teams and organizational cultures. Culture has a complex multifaceted nature (Erez \& Gati, 2004) modeled as a cultural mosaic (Chao and Moon, 2005) suggesting a complex pattern of geographic, demographic, ethnographic and associative facets making up an individual's cultural identity. Culture is a multilayered construct that includes several markers such as nationality and citizenship, national culture, ethnicity, religion, language, etc.

Culture may be looked at as the degree of heterogeneity and diversity among team member members. Cultural diversity and cultural heterogeneity may strengthen teams if the team members are capable to respect other languages and cultures. Cultural diversity is represented by differences in backgrounds, life, philosophies, norms, social identity, language, etc. Culture creates differences in group behaviors and communication. Diversity of team members involves the composition of different cultural backgrounds, unit 
affiliations, skills, etc.

Culture encompasses broad national differences to include ethnic, genetic, racial, gender, religion, associations and collectivities, and other demographic characteristics. Cultural differences among individuals from different nationalities assessed by the cultural dimension (Hofstede, 1980) may affect team effectiveness processes and outcomes. The cultural dimensions depicted by Hosftede (1980) can explain cultural differences and subtleties of culture among individuals from various nation-states, so nationality is an indicator of culture. Rao (2009b) analyze national cultural dimensions adopting normative equivalences strategies to identify relationship-building with survey-response strategies and their significance.

The GLOBE cultural project as a theoretical framework on culture identifies the national cultural dimensions of power distance, in-group collectivism, uncertainty-avoidance, and performance-orientation and gender egalitarianism. Cultural differences are conceived as ideologies and attitudes influence trust of multinational multicultural differenced teams (Cogburn \& Levinson, 2003). Baba et al. (2004) uses this framework based on cultural differences to sustain the ethno history of global virtual teams.

National culture has been depicted as the software of the mind by Hofstede (1980) to explain the different behaviors and logics of people. National culture is related to communication, trust and context as it was found on Hofstede's dimensions. National cultures influence organizational culture related to teams (Lee \& Barnett, 1997; Lindsley, 1999). Rigid classification based on the nature of national cultures does not explain movements and relocations of populations.

Multinational firms identify global knowledge relevant to management across national borders despite the values embedded in national cultures that push for knowledge and expertise operationalized with local adaptation (Sparrow et al., 2004: 110). Contrary to traditional multinational firms from developed economies, new multinational firms originated from emerging economies are more dynamic and away from path dependence without deeply ingrained organizational culture, values and structure. The new multinational 
firms from emerging economies follow some patterns of development and expansion consist with the staged theories of internationalization and product life cycle theory besides the tendency to expand in foreign markets that have similar culture.

In the global and transnational context, transnational learning structures are relevant for the global learning outcomes related to the assignment of tasks and collaborative generation of organizational knowledge among formed committees, project groups, development and diffusion of global and national policies and capabilities, capture and sharing of global organizational culture and best practices. Culture affects the way "information and knowledge is conveyed and learned" (p. 17). Transnational learning structures are more significantly to diffuse developing know-how, best practices and core competencies, development of a global organizational culture and in a lesser extent in development and adaptation of global policy (Tregaskis, Edwards, Edwards, Ferner, and Marginson, 2010).

Transnational learning structures through global policy, global culture and best practices, may contribute to global integration using mechanisms based on person to person (Sparrow et al., 2004). One form of tacit embedded organizational knowledge is cultured knowledge based on the assumptions, beliefs and norms of organizational practices and determined by the globalization priorities. Variations in cultured knowledge in multinational firms are high across the borders in different national settings. As a mechanism, socialization of cultured knowledge facilitates shared communication and understandings through the surfacing of norms and assumptions (Senge, 1990).

The role of distribution and culture of individuals have influence on team processes and outcomes. Individuals work in multinational and multicultural diverse and distributed teams have diverse national and cultural backgrounds. Multinational multicultural diverse distributed teams have become the norm prevalence in organizational settings of business and governments (Rasters, Vissers, \& Dankbear, 2002, Wright and Drewery, 2006). Multinational multicultural distributed teams focus on the geographic 
facet to frame national cultural differences to equate nationality and culture. This approach neglects the dynamic multiplicity of culture. Goodwin and Halpin (2006) found resistance in multinational and multicultural distributed teams to the development of one culture where there are several pre-existing cultures.

Multinational multicultural distributed teams may have different purposes: to conduct future research (Maruping \& Agarwal, 2004), to advice practical recommendations (Harvey et al., 2005).

Cultural distance presents two boundaries, distance and culture that presents critical discontinuities to manage for effectiveness of global organizational contexts (Cogburn \& Levinson, 2003, Watson-Manheim, Chudoba, \& Crowston, 2002), and constraints to be overcome (Yuan \& Gay, 2006). Under the assumption that the economy gains from labor division, differentiation and collective efficiency on firms of one sector cluster between each other developing specialized knowledge reinforced through a common organizational culture (Young, 1928). Organizational learning as a dynamic process of the individual knowledge moves through learning structures knowledge from the individual, group and organizational levels captured within the organizational processes, competences and culture (Huber, 1991).

The enactment of the North American Free Trade Agreement (NAFTA) and the lack of policies focusing to support and encourage entrepreneurship were two important causes that triggered the development of a new entrepreneurial culture. This new entrepreneurial culture led to the emergence of business more oriented to international markets. Davila, Pérez y Habermann (2005) use organizational culture theory to analyze the basic assumptions, shared values and behaviors of organizational members employed in Mexican multinational corporation's subsidiaries.

One relevant case is the Mexican multinational firm CEMEX. Perez Chavarria (2001) analyzes the creation of common meanings - culturethrough formal communication in a Multinational Mexican company (CEMEX). Perez Chavarria (2001) has study the way organizational culture is formally communicated in a Multinational Mexican company (CEMEX 
assuming that the organizational culture is composed essentially of cultural substance and forms (Harrison and Beyer, 1993; Bantz,1993) to reach the inference of meanings that can be taken as the basis or support of its culture. The findings reflect a possible interpretation of the culture that sustains that symbolic reality of the organization.

Multinational corporations have to foster a culture of corporate social responsibility strategy involving all stakeholders to improve the effectiveness of strategic alliances (Weyzig, 2006). Advancement of CSR in Mexican multinationals requires a commitment on a strong regulatory culture capacity building instead of taking a voluntary approach, more involvement with civil society actors and more public pressure to address specific barriers. Stakeholders of Mexican multinational firms lack engagement in a strategy of CSR due to a no ideal chaotic environment framed by historical confrontational attitudes and the lack of alliance culture, although sometimes firms may be inclined to make some philanthropic actions.

Grupo Vitro the Mexican glass multinational firm has implemented the CSR strategy in community service activities such as recycling, environmental protection and the promotion of art and culture, supporting schools, development programs and the glass museum in its founding city Monterrey (Paul et al., 2006). The strategy CSR followed by Grupo Bimbo is part of the natural activities immersed in its culture with internal and external, economic, social and environmental aims. The environmental internal purpose is to create a more environmental friendly awareness culture among its associates and use resources in the most efficient way (Grupo Bimbo, 2009, pp. 1).

Rao (2009a) examines the dimensions of national culture influencing the staffing practices in México. Rao (2009a) identifies the cultural dimensions in the Mexican culture as predictors for predominant staffing practices associated with, and proposes a model for staffing practices related to cultural dimensions. An initiative focused on Mexican culture, the Business Culture in Latin America (BUCLA) provides a solution through e-learning.

Culture may be constructed as barriers that divide individuals. Business 
community suffers from lacking business culture skills and understanding others cultures.

Human beings must be aware of our capabilities to assimilate, contribute, share an experience the new opportunities offered by the exchange of cultures. Cultural intelligence is the capability that a person has to adapt to new cultures and be effective to bridge activities and issues between two or more cultures. Full development of human potentialities requires participating actively in experiencing other cultures and ideologies of economic, political and social systems to become more cosmopolitan citizen of the world.

\section{An Institutional Analysis of the Multinational Structure}

\section{A. Case Study: Johnson Controls Inc.}

All the questions and issues rose above can be applied to the company Johnson Controls Inc. (JCI) to identify what their problems are and to know the causes and result. The company Johnson Controls (Johnson-Controls, 2010 ) is a diversified global technology industry leader serving customers in over 150 countries (Figure 1).

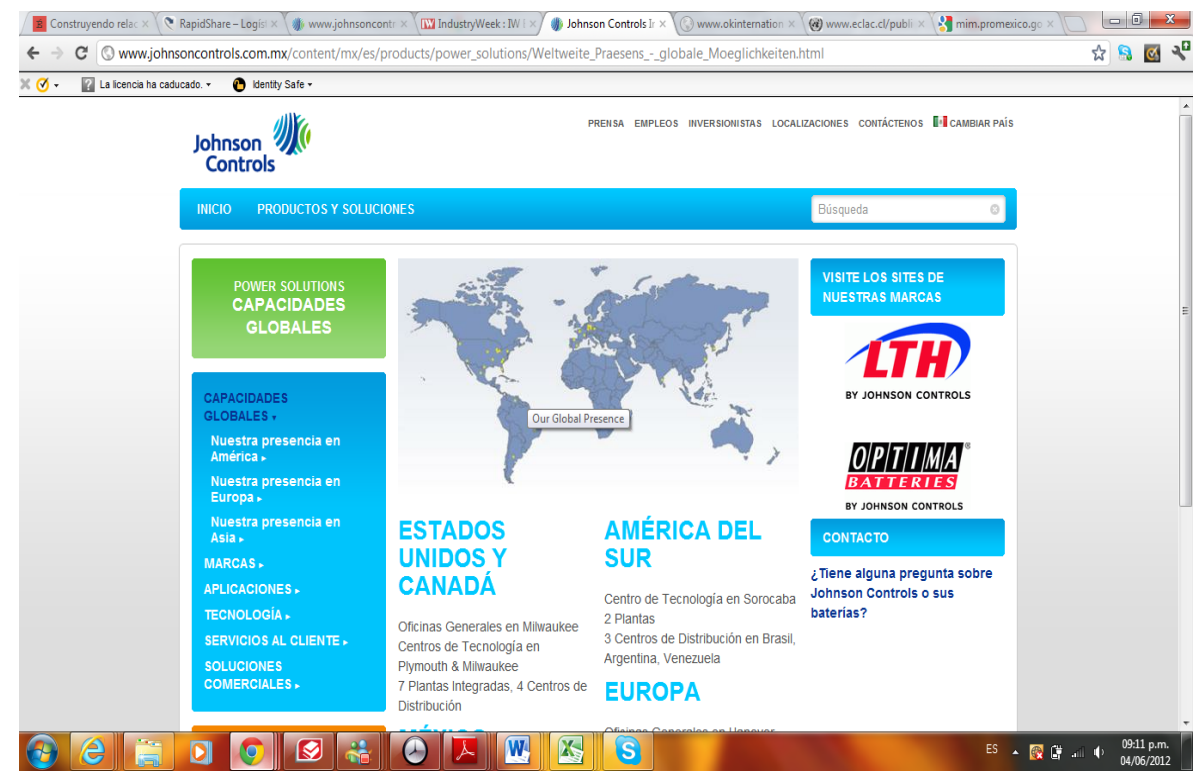

Figure 1. The Global presence of Johnson Controls, Inc. 
Source: (Johnson-Controls, 2010), Informe de empresa y sostenibilidad 2010, johnsoncontrols. Captured from http://www.johnsoncontrols.com/content/dam/WWW/jci/corporate/ sustainability/bsr2010/SPE_hires.pdf

Its 162,000 employees provide quality products, services and solutions to optimize energy and operational efficiency of buildings and leadacid batteries for cars, advanced batteries for hybrid and electric vehicles, and interior systems for cars. The firm has the commitment to sustainability, and going back to basics and origins in 1885, with the invention of the first electric environmental thermostat. Through its strategies for growth and increased market shares, the firm is committed to providing values to shareholders and the success of its customers.

JCI's values support a set of strategic objectives to manage its businesses and achieve long-term success. They expect to remain the company's values at all times at Johnson Controls. The commitment that JCO has with its employees is: "As we grow, so will do our people. We foster a culture that promotes excellent performance, teamwork, non-discrimination, leadership and growth. Our diversity of employees and leaders reflect our markets and global population" (Johnson Controls, 2010).

The company Johnson Controls Inc. continues to quantifying and managing the active participation of employees in the Global Survey for employees, along with subsequent action plans of the company, creating a cycle of continuous improvement in all strategies for staff (Tables 2 and 3).

Table 2. Levels of employee participation

\begin{tabular}{|c|c|c|c|c|c|}
\hline Year & $\begin{array}{c}\text { Blue } \\
\text { sky } \\
\text { involve } \\
\text { projects }\end{array}$ & $\begin{array}{c}\text { Employee } \\
\text { participa- } \\
\text { tion }\end{array}$ & $\begin{array}{c}\text { Hours } \\
\text { of work } \\
\text { volunteer }\end{array}$ & $\begin{array}{c}\text { Level of } \\
\text { employee } \\
\text { participation } \\
\text { in the survey }\end{array}$ & $\begin{array}{c}\text { Level of active } \\
\text { employee } \\
\text { participation }\end{array}$ \\
\hline 2010 & 930 & 14,500 & 115,600 & $91 \%$ & $71 \%$ \\
\hline 2009 & 650 & 12,500 & 105,00 & $90 \%$ & $67 \%$ \\
\hline 2008 & 530 & 11,000 & 97,000 & $86 \%$ & $61 \%$ \\
\hline 2007 & & & & $82 \%$ & $56 \%$ \\
\hline
\end{tabular}


Source: (Johnson-Controls, 2010), Informe de empresa y sostenibilidad 2010, johnsoncontrols. Captured from

http://www.johnsoncontrols.com/content/dam/WWW/jci/corporate/ sustainability/bsr2010/SPE_hires.pdf pp. 22.

Table 3. Health and safety

\begin{tabular}{|c|c|c|}
\hline Year & $\begin{array}{c}\text { Index of labor accidents } \\
\text { registered }\end{array}$ & $\begin{array}{c}\text { Index of labor accidents with } \\
\text { firing }\end{array}$ \\
\hline 2010 & 0.79 & 0.32 \\
\hline 2009 & 0.92 & 0.35 \\
\hline 2008 & 1.09 & 0.42 \\
\hline 2007 & 1.36 & 0.49 \\
\hline 2006 & 1.46 & 0.56 \\
\hline
\end{tabular}

Accidents registered by Occupational Safety and Health Administration (OSHA) U.S. American X 200,000 worked hours.

Source: (Johnson-Controls, 2010), Informe de empresa y sostenibilidad 2010, johnsoncontrols. Captured from

http://www.johnsoncontrols.com/content/dam/WWW/jci/corporate/ sustainability/bsr2010/SPE_hires.pdf pp. 22

Leadership awards. Although all data obtained by the company and the awards, always have problems in any of the plants, because you cannot have ultimate control of each and every one of them working properly (Figure 2).

\section{Leadership awards}

- Inclusion on the list of 2010 of Global Outsourcing 100 (The best suppliers of externalization services.

- Award to the industrial excellence CoreNet Global Industry Excellence Award (2009).

- $\quad$ Award to the manager of the European real state of year 2008 
- $\quad$ Award to the automation of Central Europe of the Society of Plastic Engineers Association of specialized engineers in plastics (SPE).

- $\quad$ Finalist in the North American sample of automobiles "Best Concept Car" 2009.

- Inclusion on the list "100 Best Corporate Citizens of the Business Ethics review.

- The leader business of the category "Auto parts suppliers" within the list "America Most Admired Companies of Fortune review.

- $\quad$ One of the "100 best-Managed Companies of Industry Week.

- $\quad$ One of the "50 Best Manufacturing Companies" of Industry Week review.

- One of the most adequate for stockholders of North America of Institutional Investors.

\section{Figure 2. Awards to leadership}

Source: Homor (2012). johnsoncontrols. Captured from (Johnsoncontrols, 2010)

\section{B. Analysis of the Case}

Johnson Controls in Mexico is one of the largest independent manufactures of seating and interior systems for automobiles. It has three plants in Puebla, Mexico and produces seats and seat parts, mainly for the Volkswagen assembly plant in Puebla and for Chrysler, Ford, Mercedes Benz and Nissan. The case study is the company Johnson Controls Inc., reference is made in Mexico by the fact that some branches have been flawed in the way of communication and the use to employees, to the extent that this entails has been had to make tough decisions as to close some of its plants as the case of Puebla (Table 4). 
Table 4. Branches and affiliates of Johnson Controls, Inc. that have closed.

\begin{tabular}{|c|c|}
\hline Country & $\begin{array}{l}\text { Address \& contact : type of production source } \\
\text { incentive }\end{array}$ \\
\hline South Africa & Johnson Controls Automotive (Pty) Ltd : \\
\hline South Africa & Cybertron Systems Pty. Ltd : \\
\hline Argentina & Johnson Controls Automotive Systems SRL: \\
\hline Brazil & Johnson Controls do Brazil Automotive Ltda: \\
\hline China & Beijing Johnson Controls Co. Ltd \\
\hline \multirow[t]{2}{*}{ Hong-Kong } & Johnson Controls Hong Kong Ltd : \\
\hline & Fiscal heaven, banking, judicial or free zone \\
\hline \multirow[t]{2}{*}{ Hong-Kong } & Johnson Controls Hong Kong Ltd: \\
\hline & Fiscal heaven, banking, judicial or free zone \\
\hline India & Johnson Controls (India) Private Limited : \\
\hline Malaysia & Johnson Controls (M) Sdn Bhd : \\
\hline Malaysia & Ikeda IOM Holdings : \\
\hline Mexico & Sistemas Automotrices Summa SA de CV : \\
\hline Mexico & Controles Reynosa SA de CV: \\
\hline \multirow[t]{2}{*}{ Mexico } & Maquiladora : \\
\hline & Human Right Watch \\
\hline \multirow[t]{2}{*}{ Mexico } & $\begin{array}{l}\text { ** PUEBLA CUAUTLANCINGO KM. } 117 \\
\text { AUTOPISTA MEXICO-PUEBLA NAVE } 21 \text { PARQUE } \\
\text { INDUSTRIAL \& } 22490283:\end{array}$ \\
\hline & Information system of the Maquiladora industry \\
\hline \multirow[t]{2}{*}{ Mexico } & $\begin{array}{l}\text { TLAXCALA TEOLOCHOLCO PUEBLA SANTA } \\
\text { ANNA CHIAUTEMPAN \& } 24650100:\end{array}$ \\
\hline & Information system of the Maquiladora industry \\
\hline \multirow[t]{2}{*}{ Filipinas } & Johnson Controls IFM Phils Corp : \\
\hline & Fiscal heaven, banking, judicial or free zone \\
\hline $\begin{array}{l}\text { República } \\
\text { Checa }\end{array}$ & Johnson Controls Automobilove Soucastky s.r.o : \\
\hline \multirow[t]{2}{*}{ Singapur } & Johnson Controls (s) Pte. Ltd : \\
\hline & Fiscal heaven, banking, judicial or free zone \\
\hline
\end{tabular}




\begin{tabular}{|l|l|}
\hline $\begin{array}{l}\text { Eslovaquia } \\
\text { Eslovaquia }\end{array}$ & Johnson Controls International spol s.r.o : \\
\hline Suiza Suiza & Johnson Controls Systems A.G : \\
\hline & Fiscal heaven, banking, judicial or free zone \\
\hline $\begin{array}{l}\text { Tailandia } \\
\text { Tailandia }\end{array}$ & Johnson Controls \& Summit Interiors Ltd \\
\hline
\end{tabular}

** Plant closed in the year 2012.

Source: (Trasnationale.org, 2009), Sucursales que han cerrado de Johnson Controls 2012. Obtenido de http://es.transnationale.org/empresas/johnson_ controls.php

In Mexico, working for the multinational company Johnson Controls means for workers endure bullying, abuse and violations of labor rights, which also exert Mexican Regional Federation of Labor (CROM), head of the collective bargaining agreement "(Jaimes, 2008). Therefore, the company decided to close the plant (Closes Johnson Controls plant in Puebla and dismissed 600 workers, 2012) as it is being said that "the labor problem in Johnson Controls, began in August 2010 when the union in turn was reported by workers to protect the interests of the company also overlapping bullying and increased working hours without additional remuneration".

So the social and ethical environment has great influence on the development of a company, whether as a multinational Johnson Controls is so, so bad dealings with its human capital was declining outcome yields and loyalty of employees in the company, which unfortunately happened that no company wants to happen, to close its facilities in spite of all investments already made.

Another case is happening in one of the plants in the United States, which has had many problems and has made that its complications affects organizational stability and growth, to the point that had to halt production. At the same time, this situation of the plant is affecting some other plants of suppliers for this error because lack of care in its handling and decision making that has not been the best. All this happens at the moment when problems 
are detected within the company and wholly disclaim liability to the extent that other plants and suppliers are always shifting their responsibility between each others. The fact within the country that there is no well-structured and delimited the responsibility of each post.

It is not possible to give the name, the source or the plant because there are some confidential and ethical issues, cannot be given more data. This information is only obtained from trusted individuals who carry out their activities in the Johnson Controls Inc. company. The company makes very free the development of its workers, which is not bad, but the workers see it as an outlet to relax during working hours, as the company does not give much importance by the fact that while they meet the goals in terms of outcomes, nothing happens. The fact that a company of this size denotes this type of communication problems highlights the fact that it assumes that each worker is responsible for, and ultimately their good work and achieving the goals that the company needs to continue its operation.

The reason why the company left with so many liberties the employee is because it considers that the most important values are to act with "honesty, fairness, respect and security" (Johnson Controls, 2010) and thus fostering a culture of unquestioned integrity. This pose strengthens the relationships in all businesses and functions, although these values have not had the desired result that the company needs. So to give an example, when people leave at 4 pm some employees do not take advantage of all their hours, and as elsewhere are avoiding entirely their duties and obligations as there are always workers of all kinds of different personalities and taking ethical challenges applied to each personality.

A really important factor is that the company works with a variety of cultures and consequently resulting in the emergence of communication problems. Here is important to emphasize that while the company sets standards to meet for the benefit and comfort of workers, not always have the assurance that it meets fully the later, causing simply to discourage workers with conflictive work situations (Table 5). 
Table 5. Social impact of conflictive work situations on workers at Johnson Controls, Inc.

\begin{tabular}{|l|l|l|l|}
\hline Year & Employees & Social impact: Country & Source \\
\hline 2009 & -4000 & $\begin{array}{l}\text { Internal restructuring: Johnson } \\
\text { Control closes 10 plants in the } \\
\text { world. }\end{array}$ & Reuters \\
\hline 2009 & -9300 & $\begin{array}{l}\text { Internal restructuring: Johnson } \\
\text { Control plans to close 21 plants } \\
\text { and cut 9300 jobs. In addition, it is } \\
\text { freezing new hiring and salaries, } \\
\text { eliminating annual bonuses for } \\
\text { executives and considering four- } \\
\text { day work week schedules, mostly } \\
\text { in the automotive business }\end{array}$ & Reuters \\
\hline 2008 & -280 & $\begin{array}{l}\text { Internal restructuring: Johnson } \\
\text { Controls close its plants of } \\
\text { batteries Grand-Quevilly, near } \\
\text { of Rouen, due to diminishing the } \\
\text { European market. }\end{array}$ & Les Echos \\
\hline 2007 & 140000 & $\begin{array}{l}\text { Johnson Controls close 12 of its } \\
\text { industries }\end{array}$ & Bloomering \\
\hline 2006 & -3900 & & \\
\hline
\end{tabular}




\begin{tabular}{|l|l|l|l|}
\hline 2006 & -5000 & $\begin{array}{l}\text { The company will close 16 plants } \\
\text { as part of its plan to help counter } \\
\text { rising raw-materials costs. The } \\
\text { cutbacks include 3,900 jobs in the } \\
\text { auto-interiors unit and 1,080 others } \\
\text { in the Milwakee-based company's } \\
\text { building. The cuts at the auto- } \\
\text { interiors unit involve 2,200 jobs in } \\
\text { North America, 1,450 in Europe } \\
\text { and 250 in Asia. The building } \\
\text { services unit is eliminating 200 } \\
\text { jobs in North America, 600 in } \\
\text { Europe and 280 elsewhere. Twenty } \\
\text { jobs are being trimmed from the } \\
\text { company's battery-making unit. }\end{array}$ & \\
\hline 1998 & & Closure/bankruptcy & Les Echos \\
\hline 2006 & -331 & Internal restructuring & Reuters \\
\hline 2005 & -231 & Closure/bankruptcy & Les Echos \\
\hline 2003 & 118,000 & $\begin{array}{l}\text { Violation OIT 111:pre-employment } \\
\text { pregnancy test. México }\end{array}$ & Human Rights \\
\hline 2002 & 111,000 & $\begin{array}{l}\text { Watch } \\
\text { Controls close its plant in Mil- } \\
\text { waukee, Wisconsin. Production is }\end{array}$ & Documentary \\
\hline 2001 & & & \\
\hline 1998 & 89,000 & & \\
\hline
\end{tabular}

Corporate Responsibility Magazine recognized Johnson Controls as number one among the "100 Best Corporate Citizens" in the United States, while the Ethisphere magazine said Johnson Controls among the "World's Most Ethical Companies" for the fifth consecutive year. "We have received 
recognition from many of the social indicators most prestigious investors as the Dow Jones Sustainability Index World and North America" (Johnson Controls, 2010).

Obviously all this talking does not happen in every branch of Johnson Controls. For example one of the most important plants and recognized by the administration of Barack Obama in 2011, is Johnson Controls, Inc. in Holland, Michigan. Even though that the economy is going through one of the worst recessions in the U.S., this Johnson Controls, Inc. plant has shown otherwise, and it has done on the effort required to carry out all the crises and problems as quickly and shortest possible time, all thanks to the efforts made by both the corporate and employees who have worked together to get ahead of this severe crisis.

In Mexico, Johnson Controls, Inc. there has not had the great development that was expected, because when making a comparison of how many foreign companies account in Mexico and the United States the differences of these plants is enormous. In the United States, Johnson Controls, Inc. has 500 branches while in Mexico has only 5 plants (see Annex E). Yet despite all that happened during the past year, the firm has recorded a growth in global headcount of 25000 to 162000 employees worldwide, while most of this progress comes from organic growth.

Though significantly, Johnson Controls has generated annual revenue growth in 64 of the last 65 years. It has posted gains in 20 of the last 21 years and continues developing a long history of consecutive dividends since 1887 . This is why, for employees of the company to have their own conclusions that the company only cares about the financial aspect regardless of the labor conditions of its employees.

\section{Conclusion and Recommendations}

Multinational economic organizations have been understood as the basis of the capitalist system because they have always been in constant change and growth, adapting to historical variations of both the economy and the market. It is well know beforehand, that the crisis has been quite hard, as 
it has seriously affected the activities of all enterprises of all kinds, yet the prevention measures have had to close many of its subsidiaries and branches.

The carry all this pressure, corporations should worry about other factors that are that personnel management in large multinational companies, becomes complicated communication flows, such as the case of Johnson Controls (US-Mexico). Because the mismanagement of the company, it had not been aware of all that certain factors such as the society in is developing the company's facilities is of vital importance to the achievement and success of their production, because if the company is really satisfied, it will be achieved working as a team together with senior management of the company and its workers. Therefore, the firm may well get the most benefit for both parties.

It also reinforces the idea that a firm from a developed country has certain competitive advantages, and as fits its strategy to enter a developing economy, just to get lower transaction costs and promote further work in these emerging economies. Only it is important for the multinational firms to have to evaluate and analyze what kinds of ethical challenges are handled in society, what kind of values are distinguished in the population and something very important, the monitoring that applies to perfection each and every one of the benefits, regulations and safety standards for employees to have job satisfaction needed for the proper organizational environment and, consequently, the success of the plant efficacy and production efficiency.

One of the biggest mistakes the company could make is not having more precise control of enterprise development in the standards of workers and also the profiles of each position occupied by the persons most appropriate and qualified for the job as well as seamlessly check the schedules to perfection for each of them.

\section{References}

- Arellano, D. (2009). Poder, patrón de dependencia y Nuevo institucionalismo económico. Universidad de Colorado.

- Baba, M. L., Gluesing, J., Ratner, H., \& Wagner, K. H. (2004). 
The contexts of knowing: Natural history of a globally distributed team. Journal of Organizational Behavior, 25, 547-587.

- Beck, U. (2008). ¿Qué es la Globalización? España: Paidos.

- Brannen, M. J. (2003). What is culture and why does it matter? Current conceptualizations of culture from anthropology. In N. A. Byacigiller, R. A. Goodman, \& M. E. Phillips (Eds.), Crossing cultures: Insights from master teachers (pp. 20-37). New York: Routledge.

- Chandler, F. R. (1961). Recent developments in American Business Administration and their conceptualization. (B. H. Review, Ed.) Spring.

- Chao, G. T., \& Moon, H. (2005). The cultural mosaic: A metatheory for understanding the complexity of culture. Journal of Applied Psychology, 90, 1128-1140.

- Coase, R. H. (1937). The Nature of the Firm (Vol. 4). (N. S. Economica, Ed.) JSTOR. e-consulta. (19 de marzo de 2012). Obtenido de http://e-consulta.com/index.php?option=com k2\&view=item \&id=29871 :cierra-johnson-controls-planta-enpuebla-y-despide-a-600-obreros\&Itemid=332 .

- Cogburn, D. L., \& Levinson, N. S. (2003). U.S.-Africa virtual collaboration in globalization studies: Success factors for complex, cross-national learning teams. International Studies Perspectives, 4, 31-54.

- Dávila-Martínez, A. d. R., Habermann-Gastelum, G. E., \& PérezSalazar, A. L. (2005). Culture in organizations of the computer industry: Insights from Latin America. Academy of Management, Academy of Management. Agosto.

- Enciclopedia de Economía. (2009). Recuperado el 18 de 05 de 2012, de Conceptos de economía: http://www.economia48.com/ spa/d/empresa-multinacional/empresa-multinacional.htm

- Erez, M., \& Gati, E. (2004). A dynamic, multi-level model of culture: From the micro level of the individual to the macro level 
of a global culture. Journal of Applied Psychology, 53, 583-598

- Gibson, C. B., \& Gibbs, J. L. (2006). Unpacking the concept of virtuality: The effects of geographic dispersion, electronic dependence, dynamic structure, and national diversity on team innovation. Administrative Science Quarterly, 51, 451-495.

- Goodwin, G. F., \& Halpin, S. M. (2006, May). Multinational, multicultural teams: Leadership challenges in the U.S. Army. In S. J. Zaccaro, T. Koehler, \& G. Yun (Chairs), Global at work, but local at heart! Symposium presented at the Society for Industrial and Organizational Psychology Annual Conference, Dallas, TX.

- Grupo Bimbo (2009). Responsabilidad Social En Grupo Bimbo. Grupo Bimbo's CSR Presentation 2009, pp. 1-12.

- Harvey, M., Novicevic, M. M., \& Garrison, G. (2005). Global virtual teams: A human resource capital architecture. International Journal of Human Resource Management, 16, 1583-1599.

- Hofstede, G. J. (1980). Culture's consequences. Beverly Hills, CA: Sage.

- Huber, G. P. (1991). “ Organizational Learning: The Contributing Processes and the Literatures" Organization Science, Vol. 2, No. 1, Special Issue: Organizational Learning: Papers in Honor of (and by) James G. March. (1991), pp. 88-115.

- Hymer, S. (1972). The large multinational corporation: an analysis of some motives for the international integration of business (Vol. 19(6)). (R. Economique, Ed.)

- Jaimes, G. C. (15 de abril de 2008). cimacnoticias. Recuperado el 20 de mayo de 2012, de http:/www.cimacnoticias.com.mx/ site/08041501-Acoso-psicologico.32778.0.html

- Jenks, C. (1993). Culture. London: Routledge and Kegan Paul.

- Johnson-Controls. (2010). johnsoncontrols. Obtenido de http:// www.johnsoncontrols.com/content/dam/WWW/jci/corporate/ sustainability/bsr2010/SPE_hires.pdf

- Johnsoncontrols. (2010). Recuperado el 18 de mayo de 
2012, de nuestra empresa: http://www.johnsoncontrols.es/ content/es/es/sobre_la_empresa/nuestra_empresa/premios_y_ reconocimientos.html

- Lee, M., \& Barnett, G. A. (1997). A symbols-and-meaning approach to the organizational cultures of banks in the United States, Japan, and Taiwan. Communication Research, 24, 394412.

- Lindsley, S. L. (1999). Communication and "the Mexican way": Stability and trust as core symbols in Maquiladoras. Western Journal of Communication, 63, 1-31.

- Maruping, L. M., \& Agarwal, R. (2004). Managing team interpersonal processes through technology: A task-technology fit perspective. Journal of Applied Psychology, 89, 975-990.

- McManus, S. (1972). The theory of the international firm: The multinational firm and the nation state. Toronto: G. Paquet

- North, D. (1990). Institutions, Institutional Change and Economic Performance, Cambridge University Press.

- North, D. (2005). Understanding the Process of Economic Change. Princenton: Princenton University Press.

- Osland, J., \& Bird, A. (2000). Beyond sophisticated stereotyping: Cultural sensemaking in Context. Academy of Management Executive, 14, 65-77.

- Paul, S., Samarah, I. M., Seetharaman, P., \& Myktyn, P. P. (2005). An empirical investigation of collaborative conflict management style in group support system-based global virtual teams. Journal of Management Information Systems, 21, 185-222.

- Peng, M. (2010). Estrategia Global: Enfatizando las instituciones, la cultura y la ética. Cengage, Learning.

- Peng, M. (2010). Estrategia Global: Cengage Learning.

- Perez Chavarria M. (2001) "An approach-from the standpoint of communication - to the interpretation of the organizational culture of a Mexican multinational: The cemex case" World 
Futures: Journal of General Evolution Volume 57, Issue 5, 2001, Pages $417-433$.

- Premios y reconocimientos (2010). Recuperado el 18 de 05 de 2012

- Putnam, R. (1993). Making Democracy Work: Civil Traditions in Modern Italy. Princeton: Princeton University Press.

- Rao, P. (2009a). The role of national culture on Mexican staffing practices. Employee Relations Volume: 31 Issue: 32009.

- Rao, P. (2009b) International survey research: Understanding national cultures to increase survey response rate. Cross Cultural Management: An International Journal Volume: 16 Issue: 2009.

- Rasters, G., Vissers, G. \& Dankbear, B. (2002). An inside lookRich communication through lean media in a virtual research team. Small Group Research, 33, 718-734.

- Rugman, A. M. (1981). Inside the multinationals. New York: Columbia University Press.

- Scott, R. (1995). Institutions and organizations. Stanford University, EUA: SAGE. Trasnationale.org. (2009). Obtenido de http://es.transnationale.org/empresas/johnson_controls.php.

- Senge, P. (1990). The Fifth Discipline: The Art and Practice of the Learning Organization. Currency.

- Sparrow P; Brewster C; Hillary H,2004 Globalising Human Resource Management Routledge London and New York.

- Stohl, C. (2001). Globalizing organizational communication. In F. M. Jablin \& L. L. Putnam (Eds.), The new handbook of organizational communication: Advances in theory,research, and methods (pp. 323-375). Thousand Oaks, CA: Sage.

- Ting-Toomey, S. (1999). Communicating across cultures. New York: Guilford. Townsend, A. M., DeMarie, S. M., \& Hendrickson, A. R. (1998). Virtual teams: Technology and the workplace of the future. Academy of Management Executive, 12, 17-29.

- Tregaskis, O., Edwards, T., Edwards, P., Ferner, A and Marginson, 
P. (2010). context and national embeddedness transnational learning structures in multinational firms: Organizational context and national embeddedness. Human Relations, 63(4) 471-499.

- Ulrich, B. (2008). ¿Qué es la Globalización?: Falacias del Globalismo, respuestas a la Globalización. Barcelona, España: Paidós Ibérica, S.A.

- Watson-Manheim, M. B., Chudoba, K. M., \& Crowston, K. (2002). Discontinuities and continuities: A new way to understand virtual work. Information Technology \& People, 15, 191-209.

- Weyzig, F. (2006). Local And Global Dimensions Of Corporate Social Responsibility In Mexico. SOMO (Centre For Research Of Multinational Corporations), The Nederlands.

- Wright, N. S., \& Drewery, G. P. (2006). Forming cohesion in culturally heterogeneous teams: Differences in Japanese, Pacific Islander and Anglo experiences. Cross Cultural Management, 13, 43-53.

- Yuan,Y. C., \& Gay, G. (2006). Homophily of network ties and bonding and briding social capital, in computer-mediated distributed teams. Journal of Computer-Mediated Communication, 11(4). Retrieved April 5, 2007, from http://jcmc.indiana.edu/ vol11/issue4/yuan.html.

- Young, A. 1928: Increasing returns and economic progress, Economic Journal 38, 527-42. 